\title{
Prepartum supplementation of nicotinic acid: Effects on health of the dam, colostrum quality, and acquisition of immunity in the calf
}

\author{
K. M. Aragona, ${ }^{*}$ C. E. Chapman, ${ }^{*}$ A. B. D. Pereira, ${ }^{*}$ B. J. Isenberg, ${ }^{* 1}$ R. B. Standish, ${ }^{* 2}$ C. J. Maugeri, ${ }^{*}$ \\ R. G. Cabral, $†$ and P. S. Erickson* ${ }^{3}$ \\ *Department of Biological Sciences, University of New Hampshire, Durham 03824 \\ †Famo Feeds Inc., Freeport, MN 56331
}

\begin{abstract}
Nicotinic acid (NA) has been shown to reduce lipolysis, alter milk components and the ruminal environment, and increase blood flow. Increased blood flow to the mammary gland during colostrogenesis might increase nutrients and immunoglobulin concentration of colostrum. Twenty-six multiparous Holstein cows were housed in a tiestall barn. Cows were blocked by expected calving date and randomly assigned to 1 of 2 treatments 4 wk prepartum: (1) $0 \mathrm{~g} / \mathrm{d}$ of NA (control, CON) or (2) $48 \mathrm{~g} / \mathrm{d}$ of NA (NA). Total mixed ration amounts fed and refused were measured daily to determine dry matter intake. Blood samples were collected from dams every Monday, Wednesday, and Friday from the coccygeal vein or artery and were analyzed for glucose, nonesterified fatty acids (NEFA), and $\beta$-hydroxybutyrate (BHB). Colostrum was collected and weighed within 90 min of parturition. Colostral immunoglobulin G ( $\operatorname{IgG}$ ) concentration was analyzed using radial immunodiffusion assay. Calves were removed from their dams before suckling and weighed within 30 min after birth. Calves received $3 \mathrm{~L}$ of a lacteal-based colostrum replacer that provided a total of $225.8 \mathrm{~g}$ of IgG within $2 \mathrm{~h}$ of birth. Calf blood samples were collected via jugular venipuncture at 0 and $24 \mathrm{~h}$ of age and analyzed for $\operatorname{IgG}$ concentration and determination of apparent efficiency of absorption. Colostrum yield, dry matter intake, IgG yield, and fat and solids percentage of colostrum did not differ between treatments. Serum concentrations of glucose and BHB were not affected by treatment. We detected an effect of week on serum glucose concentrations at calving and on serum BHB concentrations at 1 wk postpartum. There was a treatment by week effect for serum NEFA concentrations
\end{abstract}

\footnotetext{
Received November 5, 2015.

Accepted January 6, 2016.

${ }^{1}$ Present address: Brown's Feeds, Birdsboro, PA 19508.

${ }^{2}$ Present address: Poulin Grain, Newport, VT 05855.

${ }^{3}$ Corresponding author: peter.erickson@unh.edu
}

at 1 wk postpartum, where cows that received NA prepartum had higher serum NEFA concentration than CON cows, indicating that a NEFA rebound occurred. No differences were observed for calf body weight, 0- or 24-h serum IgG concentration, or apparent efficiency of absorption. Supplementation of NA increased IgG concentration in colostrum from 73.8 to $86.8 \mathrm{~g} / \mathrm{L}$. Results indicate that $48 \mathrm{~g} / \mathrm{d}$ of supplemental NA during the prepartum period improved colostrum quality.

Key words: nicotinic acid, prepartum, colostrum, dairy calf, immunoglobulin $\mathrm{G}$

\section{INTRODUCTION}

Effects of supplemental nicotinic acid (NA) on metabolism in pre- and postpartum cattle have been widely studied (Neihoff et al., 2009a), but little is known about its possible effects on colostrum quality or calf immunity, which are key factors for dairy farm success and profitability. Acquisition of immunity in the neonate is dependent on consumption of high-quality colostrum. A nationwide evaluation of colostrum quality in the United States found that $>60 \%$ of colostrum does not meet industry recommendations of $\geq 50 \mathrm{~g}$ of $\mathrm{IgG} / \mathrm{L}$ and a total plate count $<100,000 \mathrm{cfu} / \mathrm{mL}$ (Morrill et al., 2012). The USDA National Animal Health Monitoring System (NAHMS, 2007) reported that one-fifth of heifer calves do not achieve successful passive transfer. Supplemental NA can increase blood flow, which may increase nutrients and immunoglobulin concentration in colostrum if supplemented during colostrogenesis.

Colostrogenesis is a unique stage in prepartum mammary gland development when maternal immunoglobulins are transferred from the blood into mammary secretions (Barrington et al., 2001). This distinct phase of development begins about 3 wk prepartum and ceases just before parturition and the onset of lactation (Brandon et al., 1971). Immunoglobulin G is the most abundant immunoglobulin present, accounting for 85 to $90 \%$ of total Ig (Butler, 1969; Sasaki et al., 1976; Larson et al., 1980). Due to the 6-layer synepi- 
theliochorial placenta in bovines, transfer of maternal immunoglobulins does not occur in utero, rendering the calf hypogammaglobulinemic (Lopez et al., 1988). For this reason, it is vital that calves receive high-quality colostrum as soon as possible after birth and within $24 \mathrm{~h}$, before complete gut closure occurs (Arthington et al., 2000). Calves that do not receive colostrum will lack necessary antibodies and many other nutrients to fight disease and survive. At $24 \mathrm{~h}$ of age, calves should achieve a minimum of $10 \mathrm{~g} / \mathrm{L}$ of $\mathrm{IgG}$ in plasma (Quigley and Drewry, 1998).

Proper nutrition in the prepartum period affects acquisition of immunity in the newborn calf (Burton et al., 1984; Hough et al., 1990) and colostrum quality (Fatahnia et al., 2012). During the last trimester, the developing fetus requires greater nutrients, as total fetal weight gain is greatest during this time (Bell, 1995). Proper feeding of the prefresh cow requires meeting the needs of both the dam and the developing fetus.

Nicotinic acid has been used in humans as an antilipolytic remedy (Carlson, 2005). It lowers triglyceride and low-density lipoprotein cholesterol levels and alters lipolysis via a $\mathrm{G}$ protein-coupled receptor (GPR) 109A (Lorenzen et al., 2001; Tunaru et al., 2003). Recent work by Titgemeyer et al. (2011) with cattle detected the presence of GPR109A in tail head, back, and perirenal fat, longissimus muscle, liver tissue, and 5 regions of the brain: hypothalamus, thalamus, cerebellum, cerebral cortex, and brain stem. When supplemented at pharmacological doses in cattle, NA inhibits lipolysis via stimulation of GPR109A (Tunaru et al., 2003; Benyó et al., 2006). Nicotinic acid reduces adenylyl cyclase activity, causing inhibition of cyclic AMP (cAMP) production (Harvey and Ferrier, 2011). If cAMP concentrations fail to rise, protein kinase A will not be able to phosphorylate hormone sensitive lipase into its active form. If hormone sensitive lipase is inactive, it is unable to break down triglycerides in adipose tissue (Harvey and Ferrier, 2011), thus reducing the release of nonesterified fatty acids (NEFA) into the blood (Neihoff et al., 2009a; Kang et al., 2011; Morey et al., 2011).

Tissue requirements for NA in dairy cattle have not been determined experimentally (Neihoff et al., 2009a). In addition to NA supplied from feed, many mammals are able to synthesize NA from tryptophan or quinolinic acid, although dairy cattle are relatively inefficient at this conversion (Frye et al., 1991; Flachowsky, 1993). Microbial synthesis serves as another source of NA. Ruminal production of NA in a $650-\mathrm{kg}$ cow producing $35 \mathrm{~kg} / \mathrm{d}$ of $4 \% \mathrm{FCM}$ was estimated to be $1,804 \mathrm{mg} / \mathrm{d}$ (NRC, 2001). However, it is speculated that ruminal bacteria do not synthesize more NA than is required for their own growth and function because de novo syn- thesis of the vitamin is an energy-demanding process (Hannah and Stern, 1985; Abdouli and Schaefer, 1986; Doreau and Ottou, 1996).

A major drawback of NA supplementation in humans has been an unpleasant flushing response. Tunaru et al. (2003) and Benyó et al. (2006) found that the GPR109A receptor is also involved in a cutaneous vasodilation response. The GPR109A receptor is expressed in Langerhans cells, immune cells that densely populate the skin. Activation of the GPR109A receptor causes a classic response from these immune cells: activation of a $G \beta \gamma-$ mediated phospholipase C receptor (Benyó et al., 2006). Activation of this receptor causes a conformational change in membrane-embedded $\mathrm{Ca}^{2+}$ channels, leading to a temporary increase in $\mathrm{Ca}^{2+}$ concentrations in the cytoplasm. This increase in concentration activates the enzyme Ca-dependent phospholipase $\mathrm{A}_{2}$. This enzyme catalyzes hydrolysis of phospholipids from membranes and lipoproteins, yielding arachidonic acid, a precursor of eicosanoids, such as prostaglandins. Prostaglandin $\mathrm{E}_{2}$ and prostaglandin $\mathrm{D}_{2}$ are released from the Langerhans cells and cause vasodilation in the skin (Benyó et al., 2005, 2006). Supplemental NA in the prepartum period could increase blood flow during colostrogenesis, resulting in a higher concentration of IgG in colostrum.

The objectives of this experiment were (1) to determine if supplementing NA during the prepartum period affects colostrum quality, DMI, or blood metabolites of the dam, and (2) to determine if NA supplementation to the dam affects IgG absorption in the calf via in utero effects. Our hypothesis was that supplemental NA during the prepartum period would increase colostral IgG concentration and decrease serum NEFA and BHB concentrations in the dam.

\section{MATERIALS AND METHODS}

\section{Experimental Design and Animal Management}

This experiment was reviewed and approved by the University of New Hampshire Institutional Animal Care and Use Committee (Protocol \#131103).

Twenty-six multiparous Holstein cows were blocked by expected calving date and randomly assigned to 1 of 2 treatments: (1) $0 \mathrm{~g} / \mathrm{d}$ NA (control, CON) or (2) $48 \mathrm{~g} / \mathrm{d}$ NA (NA), both with $52 \mathrm{~g} / \mathrm{d}$ of corn meal as a carrier. Treatments were top dressed at each feeding, beginning 4 wk prepartum, and continued until calving. Cows were housed in a tiestall barn, and stalls had mattresses bedded with kiln-dried sawdust. Cows had access to water at all times via automated water bowls (DeLaval, Tumba, Sweden). Each cow had an individual wooden feed tub $(90 \times 90 \times 90 \mathrm{~cm})$ to allow 
for measurements of daily feed intake. As cows neared calving, they were moved into individual maternity pens.

\section{Colostrum Collection and Analysis}

Cows that experienced difficulty calving were not used for this study. Within 90 min of calving, colostrum was collected from dams and weighed, and 2 aliquots were taken. One aliquot was sent to Dairy One Laboratory (Ithaca, NY) for analysis of fat (method 989.05), protein (method 991.20), and solids (method 990.20) percentages according to AOAC International methods (AOAC International, 2006). The second aliquot was frozen at $-20^{\circ} \mathrm{C}$ until further analysis of $\mathrm{IgG}$ content by radial immunodiffusion (RID) assay (Triple J Farms, Bellingham, WA).

\section{Cow Measurements}

All cows were weighed (Cardinal, Northeast Scale Co. Inc., Hooksett, NH) before starting treatments, and every Monday thereafter until calving. Blood samples were collected from each cow before administration of treatments. Once cows were assigned to treatments, blood samples were collected every Monday, Wednesday, and Friday at $1130 \mathrm{~h}(3.5 \mathrm{~h}$ after feeding) via coccygeal vein or artery into $10-\mathrm{mL}$ tubes (BD Vacutainer, Becton Dickinson, Franklin Lakes, NJ) containing sodium heparin. Blood samples were collected at calving and $24 \mathrm{~h}$ and $7 \mathrm{~d}$ postpartum. Samples were placed on ice until they were centrifuged at 1,278 $\times g$ at $4^{\circ} \mathrm{C}$ for $20 \mathrm{~min}$ (5430R, Eppendorf, Hamburg, Germany). Serum was aspirated and stored at $-20^{\circ} \mathrm{C}$ until further analysis for glucose, NEFA, and BHB. Serum glucose concentrations were measured in duplicate using Wako Autokit for Glucose (Wako Diagnostics, Mountain View, CA). Concentrations were read on a DU 520 spectrophotometer according to manufacturer's instructions (Beckman Coulter, Brea, CA). Serum NEFA concentrations were measured in triplicate using the Wako NEFA-HR (2) kit (Wako Diagnostics). Serum BHB concentrations were measured in triplicate using the $\beta$-hydroxybutyrate Colorimetric Assay Kit from Cayman Chemical (Ann Arbor, MI). Both serum NEFA and BHB concentrations were read using a plate reader (Chromate, Awareness Technology Inc., Palm City, FL) according to the manufacturer's instructions. Urine samples were also collected Monday, Wednesday, and Friday just before blood sampling until calving, and $\mathrm{pH}$ was analyzed using a portable $\mathrm{pH}$ probe (VWR Symphony, Thermo Scientific, Radnor, PA).

\section{Calf Care and Blood Collection for IgG Assay and Apparent Efficiency of Absorption}

Calves were removed within $30 \mathrm{~min}$ of birth and before nursing. Calves were weighed (A and A Scales, Prospect Park, NJ), placed into an individual pen in a naturally ventilated, enclosed calf room, and navels were dipped in $7 \%$ iodine. Pens had a mattress topped with kiln-dried sawdust. Calves remained on study until $24 \mathrm{~h}$ of age.

Calves were fed $3 \mathrm{~L}$ of a lacteal-based colostrum replacer that provided a total of $225.8 \mathrm{~g}$ of IgG (Saskatoon Colostrum Co. Ltd., Saskatoon, SK, Canada) within $2 \mathrm{~h}$ of birth. To determine whether NA supplementation to the dam had any effects on the calf in utero, calves were not fed maternal colostrum. If calves did not immediately consume the colostrum replacer, it was kept warm and reintroduced $1 \mathrm{~h}$ later. If the remaining colostrum replacer was still refused, it was fed via esophageal tube.

Blood samples were collected into $10-\mathrm{mL}$ tubes (BD Vacutainer) containing sodium heparin via jugular venipuncture at 0 and $24 \mathrm{~h}$ of age. Samples were placed on ice and centrifuged at $1,278 \times g$ at $4^{\circ} \mathrm{C}$ for $20 \mathrm{~min}$ (5430R, Eppendorf). Serum was harvested and stored at $-20^{\circ} \mathrm{C}$ until further analysis for IgG concentration by RID (Triple J Farms).

Apparent efficiency of absorption (AEA) at $24 \mathrm{~h}$ of age was estimated using the following equation according to Quigley et al. (1998) and adjusted for colostrum replacer according to Cabral et al. (2015):

$$
\begin{gathered}
{[(24 \text {-h plasma } \operatorname{IgG}(\mathrm{g} / \mathrm{L}) \times \mathrm{BW}(\mathrm{kg}) \times 0.0825) /} \\
\operatorname{IgG} \text { intake }(\mathrm{g} / \mathrm{L})] \times 100 .
\end{gathered}
$$

\section{Feed Analysis}

All feed ingredients were analyzed at Analab (Fulton, IL) before the start of the experiment for ADF (method 973.18), NDF (method 2002.04), CP (method 990.03), starch (glucose was extracted from starch and analyzed by enzymatic methods from Trinder, 1969a,b), crude fat (method 920.39), ash (method 942.05), Ca, P, Mg, and K (method 98.01), and S (method 923.01) according to AOAC International methods (AOAC International, 1999). Diets were adjusted as needed based on DM of ingredients and nutrient analysis.

Total mixed ration amounts fed and refused were measured daily at $0800 \mathrm{~h}$ to determine DMI. Samples of TMR and orts were collected daily and frozen for later analysis. Frozen samples were thawed and dried in a forced hot-air convection oven at $55^{\circ} \mathrm{C}$ for $48 \mathrm{~h}$ to 
determine DM (Binder, Bohemia, NY). Ort samples were composited weekly by cow, and TMR samples were composited monthly by cow. Samples were ground through a 1-mm screen using a Wiley mill (Thomas Scientific, Swedesboro, NJ). Samples were sent to Analab for analysis of ADF, NDF, CP, starch, fat, ash, Na, P, $\mathrm{K}, \mathrm{Mg}, \mathrm{Ca}, \mathrm{Mn}, \mathrm{Fe}, \mathrm{Cu}, \mathrm{Zn}, \mathrm{S}$, and $\mathrm{Cl}$, as previously described.

\section{Statistical Analysis}

Serum glucose, NEFA, and BHB, DMI, and cow BW data were analyzed as a randomized complete block design with repeated measures using the MIXED procedure of SAS 9.4 (SAS Institute Inc., Cary, NC) according to the following model:

$$
\mathrm{Y}_{\mathrm{ijk} l}=\mu+\mathrm{B}_{\mathrm{i}}+\mathrm{N}_{\mathrm{j}}+\mathrm{W}_{\mathrm{k}}+\mathrm{L}_{\mathrm{l}}+\beta \mathrm{X}_{\mathrm{ij}}+\mathrm{NW}_{\mathrm{jk}}+\mathrm{e}_{\mathrm{ijk} \mathrm{k}} \text {, }
$$

where $\mathrm{Y}_{\mathrm{ijkl}}=$ the dependent variable; $\mu=$ the overall mean; $\mathrm{B}_{\mathrm{i}}=$ the random effect of block $\mathrm{i}(\mathrm{i}=1, \ldots, 13)$; $\mathrm{N}_{\mathrm{j}}=$ the fixed effect of the jth nicotinic acid level $(\mathrm{j}=$ $0,48) ; \mathrm{W}_{\mathrm{k}}=$ the fixed effect of the kth week relative to calving $(\mathrm{k}=-4, \ldots, 1) ; \mathrm{L}_{\mathrm{l}}=$ the fixed effect of the lth lactation $(1=2,3,4,7,8) ; \beta=$ the regression (covariate coefficient); $\mathrm{X}_{\mathrm{ij}}=$ the covariate measurement; $\mathrm{NW}_{\mathrm{jk}}$ $=$ the fixed interaction between the jth niacin level and the kth week; and $\mathrm{e}_{\mathrm{ijk} k}=$ the residual error $\sim N\left(0, \sigma^{2}{ }_{\mathrm{e}}\right)$.

In this model, the random effect of cow within block subclass was used as the error term for the effect of treatment. The residual errors are errors within cow across time and represent errors from repeated measurements in the experimental units (cows). All variables, except BW, were modeled using a first-order autoregressive covariance spatial structure. First-order autoregressive resulted in the smallest Bayesian information criteria of the 4 covariate structures tested: compound symmetry, unstructured, Toeplitz, and first autoregressive. Cow BW was modeled using compound symmetry covariance spatial structure as it resulted in the smallest Bayesian information criterion. Degrees of freedom were calculated using the Kenward-Roger approximation option of the MIXED procedure. Covariate $P$-values for NEFA, DMI, and milk production were $>0.25$; therefore, they were removed from the models.

Urine $\mathrm{pH}$ data were transformed into $\mathrm{H}^{+}$ion concentration (Murphy, 1982) and analyzed in a randomized complete block design using the GLM procedure of SAS 9.4 (SAS Institute Inc.) according to the following model:

$$
Y_{i j k}=\mu+B_{i}+N_{j}+W_{k}+N_{j k}+e_{i j k},
$$

where $Y_{i j k}=$ the dependent variable; $\mu=$ the overall mean; $B_{i}=$ the random effect of block $i(i=1, \ldots, 13)$; $\mathrm{N}_{\mathrm{j}}=$ the fixed effect of the $\mathrm{jth}$ nicotinic acid level $(\mathrm{j}=$ $0,48) ; W_{k}=$ the fixed effect of the kth week relative to calving $(\mathrm{k}=-4, \ldots, 1) ; \mathrm{NW}_{\mathrm{jk}}=$ the fixed interaction between the jth niacin level and the kth week; and $e_{\mathrm{ijk}}$ $=$ the residual error $\sim N\left(0, \sigma^{2}{ }_{\mathrm{e}}\right)$.

Colostrum IgG concentration and yield, colostrum volume, and protein, fat, and solids percentage data were analyzed as a randomized complete block design using the MIXED procedure of SAS 9.4 (SAS Institute Inc.) according to the following model:

$$
\mathrm{Y}_{\mathrm{ij}}=\mu+\mathrm{B}_{\mathrm{i}}+\mathrm{N}_{\mathrm{j}}+\beta \mathrm{X}_{\mathrm{ij}}+\mathrm{e}_{\mathrm{ij}} \text {, }
$$

where $\mathrm{Y}_{\mathrm{ij}}=$ the dependent variable; $\mu=$ the overall mean; $B_{i}=$ the random effect of block $\mathrm{i}(\mathrm{i}=1, \ldots, 13)$; $\mathrm{N}_{\mathrm{j}}=$ the fixed effect of the $\mathrm{jth}$ nicotinic acid level $(\mathrm{j}=$ $0,48) ; \beta=$ the regression (covariate coefficient); $\mathrm{X}_{\mathrm{ij}}=$ the covariate measurement; and $\mathrm{e}_{\mathrm{ij}}=$ the residual error $\sim \mathrm{N}\left(0, \sigma_{\mathrm{e}}^{2}\right)$. In this model, the random effect of cow within block subclass was used as the error term for the effect of treatment. Degrees of freedom were calculated using the Kenward-Roger approximation option of the MIXED procedure.

Calf BW, 0-h and 24-h IgG concentrations, and AEA data were analyzed as a randomized complete block design using the MIXED procedure of SAS 9.4 (SAS Institute Inc.) according to the following model:

$$
\mathrm{Y}_{\mathrm{ij}}=\mu+\mathrm{B}_{\mathrm{i}}+\mathrm{N}_{\mathrm{j}}+\mathrm{e}_{\mathrm{ij}},
$$

where $\mathrm{Y}_{\mathrm{ij}}=$ the dependent variable; $\mu=$ the overall mean; $B_{i}=$ the random effect of block i $(i=1, \ldots, 13)$; $\mathrm{N}_{\mathrm{j}}=$ the fixed effect of the $\mathrm{jth}$ nicotinic acid level $(\mathrm{j}=$ $0,48)$; and $\mathrm{e}_{\mathrm{ij}}=$ the residual error $\sim N\left(0, \sigma^{2}{ }_{\mathrm{e}}\right)$. In this model, the random effect of calf within treatment subclass was used as the error term for effect of treatment. Degrees of freedom were calculated using the KenwardRoger approximation option of the MIXED procedure.

For all variables, significant treatment and interaction effects were noted at $P \leq 0.05$ and trends were noted at $0.05<P \leq 0.1$.

\section{RESULTS}

\section{Diet Composition}

Diet composition and nutrient analysis of the TMR is presented in Table 1. The diet was formulated to meet or exceed the nutrient requirements for prepartum dairy cows (NRC, 2001). Acid detergent fiber analysis 
Table 1. Ingredient and chemical composition (\% of DM unless otherwise noted; \pm SD) of the prepartum diet

\begin{tabular}{lc}
\hline Item & Value \\
\hline Dietary ingredient & \\
Corn silage & 37.4 \\
Grass haylage & 30.0 \\
RUP mix (Provaal Elite) ${ }^{1}$ & 2.1 \\
Dry cow mix & \\
Nutrient content & 30.4 \\
CP & \\
ADF & $27.4 \pm 1.8$ \\
NDF & $40.6 \pm 2.7$ \\
NFC & $14.0 \pm 1.3$ \\
Starch & $35.6 \pm 3.2$ \\
Fat & $17.1 \pm 2.4$ \\
Lignin & $2.7 \pm 0.2$ \\
Ash & $3.6 \pm 0.2$ \\
Na & $8.8 \pm 0.5$ \\
Mg & $0.2 \pm 0.04$ \\
P & $0.6 \pm 0.04$ \\
S & $0.3 \pm 0.02$ \\
K & $0.4 \pm 0.05$ \\
Ca & $1.6 \pm 0.1$ \\
Cl & $0.7 \pm 0.2$ \\
Mn (mg/kg) & $0.8 \pm 0.1$ \\
Fe (mg/kg) & $81.6 \pm 5.3$ \\
Zn (mg/kg) & $282.7 \pm 62.1$ \\
RuP $/ \mathrm{kg})$ & $15.8 \pm 2.1$ \\
mix (Provagl & $89.9 \pm 6.3$ \\
\hline
\end{tabular}

${ }^{1}$ RUP mix (Provaal Elite, Perdue, Kings Mountain, NC) contained $93 \% \mathrm{CP}, 1.1 \%$ fat, $1.3 \%$ ash, $0.2 \% \mathrm{Ca}, 0.1 \% \mathrm{P}, 0.2 \% \mathrm{Mg}, 0.3 \% \mathrm{Cl}$, $0.2 \% \mathrm{~K}, 0.2 \% \mathrm{Na}, 1.4 \% \mathrm{~S}, 8.9 \mathrm{mg} / \mathrm{kg} \mathrm{Cu}, 2,315 \mathrm{mg} / \mathrm{kg} \mathrm{Fe}, 8.7 \mathrm{mg} / \mathrm{kg}$ $\mathrm{Mn}, 0.2 \mathrm{mg} / \mathrm{kg}$ Se, $35 \mathrm{mg} / \mathrm{kg} \mathrm{Zn}$, and $4.8 \% \mathrm{Arg}, 5.4 \%$ His, $1.2 \% \mathrm{Ile}$, $12.6 \%$ Leu, $8.8 \%$ Lys, $3.9 \%$ Met, $6.8 \%$ Phe, $3.4 \%$ Thr, $1.2 \%$ Trp and $6.3 \%$ Val (\% as CP).

${ }^{2}$ Dry cow mix (Poulin Grain, VT) contained 19.8\% CP, $13.8 \%$ ADF, $21.6 \%$ NDF, $34.8 \%$ NFC, $7.2 \%$ RUP, $15.9 \%$ starch, $7.6 \%$ sugar, $2.5 \%$ fat, $1.9 \% \mathrm{Ca}, 0.3 \% \mathrm{P}, 1.2 \% \mathrm{Mg}, 1.1 \% \mathrm{~K}, 0.9 \% \mathrm{~S}, 1 \mathrm{mg} / \mathrm{kg} \mathrm{Se}, 0.6 \% \mathrm{Na}$, $1.6 \% \mathrm{Cl}, 444.8 \mathrm{IU} / \mathrm{kg}$ of vitamin $\mathrm{E}$.

of ort samples was $27.8 \pm 1.9$ for CON and $27.9 \pm 2.1$ for NA. Neutral detergent fiber analysis of ort samples was $43.1 \pm 3.0$ for $\mathrm{CON}$ and $42.1 \pm 2.2$ for NA. Crude protein analysis of ort samples was $13.5 \pm 1.0$ for CON and $14.1 \pm 1.6$ for NA. These data indicate that this NA dosage did not result in sorting of the TMR.

\section{Cow Measurements}

Average days on study were $28.9 \pm 4.7$ for $\mathrm{CON}$ and $25.8 \pm 4.5$ for NA. Initial BW of all cows were similar: $798.3 \pm 5.8 \mathrm{~kg}$ for CON and $791.5 \pm 6.1 \mathrm{~kg}$ for NA. Initial serum concentrations of BHB, glucose, and NEFA were similar: $0.49 \pm 0.02 \mathrm{mmol} / \mathrm{L}$ for $\mathrm{CON}$ and $0.45 \pm$ $0.02 \mathrm{mmol} / \mathrm{L}$ for NA; $60.9 \pm 2.3 \mathrm{mg} / \mathrm{dL}$ for $\mathrm{CON}$ and $64.3 \pm 2.3 \mathrm{mg} / \mathrm{dL}$ for $\mathrm{NA} ; 122.3 \pm 76.1 \mu \mathrm{Eq} / \mathrm{L}$ for $\mathrm{CON}$ and $139.7 \pm 75.6 \mu \mathrm{Eq} / \mathrm{L}$ for $\mathrm{NA}$, respectively.

Treatment for ketosis was administered to $4 \mathrm{CON}$ cows and 2 NA cows. Treatment for udder edema was administered to $1 \mathrm{CON}$ cow and $1 \mathrm{NA}$ cow. One NA cow was diagnosed and treated for milk fever. Retained placenta occurred in $2 \mathrm{CON}$ cows and $1 \mathrm{NA}$ cow. These metabolic disorders occurred independently of one another to individual cows.

Nicotinic acid did not affect DMI or urine pH (Table 2 ). Week effects were noted for serum glucose and BHB concentrations (Table 2). We detected a week effect for serum BHB concentrations due to elevated levels $1 \mathrm{wk}$ postpartum (Table 2), and a treatment by week effect for serum NEFA concentrations at 1 wk postpartum. Cows that received supplemental NA in the prepartum period had higher serum NEFA concentrations than CON cows $(P=0.003$, Table 2 , Figure 1$)$, indicating a NEFA rebound.

Supplemental NA increased colostral IgG concentration from 73.8 to $86.8 \mathrm{~g} / \mathrm{L}(P=0.01$, Table 3$)$. Nicotinic acid had no effect on colostrum yield, IgG yield, or fat and solids percentage (Table 3 ). Nicotinic acid tended to increase protein percentage of colostrum $(P$ $=0.09$, Table 3$)$.

\section{Calf Measurements}

One CON cow had twins and 2 NA cows had twins. Mean initial IgG concentration was 0.41 and $0.72 \mathrm{~g} / \mathrm{L}$

Table 2. Cow DMI, BW, urine $\mathrm{pH}$ and blood metabolites in prepartum cows fed either 0 or $48 \mathrm{~g} / \mathrm{d}$ of nicotinic acid

\begin{tabular}{|c|c|c|c|c|c|c|}
\hline \multirow[b]{2}{*}{ Item } & \multicolumn{2}{|c|}{ Treatment $(\text { Trt })^{1}$} & \multirow[b]{2}{*}{ SEM } & \multicolumn{3}{|c|}{$P$-value } \\
\hline & $\mathrm{CON}$ & NA & & Trt & Week & Trt $\times$ Week \\
\hline DMI, $\mathrm{kg} / \mathrm{d}$ & 16.0 & 14.6 & 0.6 & 0.15 & $<0.001$ & - \\
\hline $\mathrm{BW}, \mathrm{kg}$ & 812.0 & 809.3 & 4.7 & 0.69 & $<0.001$ & - \\
\hline Urine $\mathrm{pH}^{2}$ & 6.9 & 7.1 & $4.17 \times 10^{-8}$ & 0.51 & 0.43 & - \\
\hline Glucose, $\mathrm{mg} / \mathrm{dL}$ & 69.5 & 70.6 & 0.99 & 0.40 & $<0.001$ & - \\
\hline $\mathrm{NEFA}^{3}{ }^{3} \mu \mathrm{Eq} / \mathrm{L}$ & 305.9 & 378.2 & 72.3 & $<0.001$ & $<0.001$ & 0.003 \\
\hline $\mathrm{BHB}, \mathrm{mmol} / \mathrm{L}$ & 0.50 & 0.43 & 0.02 & 0.23 & $<0.001$ & - \\
\hline
\end{tabular}

${ }^{1}$ Treatments: $\mathrm{CON}=$ control, basal TMR with $0 \mathrm{~g} / \mathrm{d}$ of nicotinic acid; NA = nicotinic acid, basal TMR with $48 \mathrm{~g} / \mathrm{d}$ of nicotinic acid.

${ }^{2}$ Urine $\mathrm{pH}$ standard error in $\mathrm{H}^{+}$concentration.

${ }^{3}$ Nonesterified fatty acids. 
Table 3. Colostrum composition data of cows fed either 0 or $48 \mathrm{~g} / \mathrm{d}$ of nicotinic acid

\begin{tabular}{lrrrr}
\hline & \multicolumn{2}{c}{ Treatment $^{1}$} & & \\
\cline { 2 - 3 } Item & CON & NA & SEM & $P$-value \\
\hline Colostrum yield, L & 10.6 & 9.5 & 0.6 & 0.19 \\
Protein, \% & 14.7 & 17.9 & 1.3 & 0.09 \\
Fat, \% & 5.5 & 4.7 & 0.8 & 0.45 \\
Solids, \% & 23.9 & 22.9 & 1.9 & 0.70 \\
IgG yield, g & 749 & 773.8 & 81.6 & 0.80 \\
IgG, g/L & 73.8 & 86.8 & 3.1 & 0.01 \\
\hline
\end{tabular}

${ }^{1}$ Treatments: $\mathrm{CON}=$ control, basal TMR with $0 \mathrm{~g} / \mathrm{d}$ of nicotinic acid; $\mathrm{NA}=$ nicotinic acid, basal TMR with $48 \mathrm{~g} / \mathrm{d}$ of nicotinic acid.

for calves of CON and NA cows, respectively. One of the 29 calves on study had failure of passive transfer; the $24-\mathrm{h} \operatorname{IgG}$ concentration was $7.8 \mathrm{~g} / \mathrm{L}$. This calf was a twin born from a NA cow, and her twin obtained passive transfer with a serum $\operatorname{IgG}$ concentration of 14.1 $\mathrm{g} / \mathrm{L}$ at $24 \mathrm{~h}$. The calf with failure of passive transfer was $>2.5$ standard deviations from the mean, deemed an outlier, and therefore removed from the statistical analyses. In total, 14 calves born from CON cows and 14 calves born from NA cows were used. Nicotinic acid supplementation of dams did not affect 0- and 24-h serum IgG concentration, AEA, or calf BW (Table 4).

\section{DISCUSSION}

The hypothesis of this experiment was that supplemental NA in the prepartum diet would increase colos-

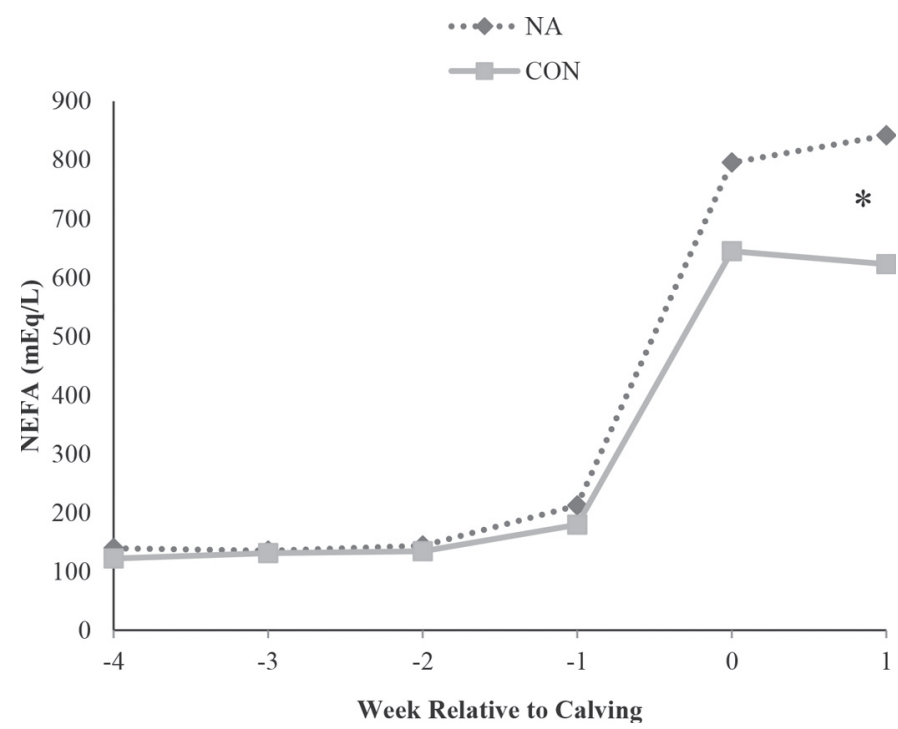

Figure 1. Weekly serum nonesterified fatty acid (NEFA) concentration for cows fed either $0(\mathrm{CON})$ or $48(\mathrm{NA}) \mathrm{g} / \mathrm{d}$ of nicotinic acid. *Treatment $\times$ week interaction $(P=0.003)$.
Table 4. Calf BW, 0 - and 24-h serum IgG concentration and apparent efficiency of absorption (AEA) data of calves born of cows fed either 0 or $48 \mathrm{~g} / \mathrm{d}$ of nicotinic acid

\begin{tabular}{|c|c|c|c|c|}
\hline \multirow[b]{2}{*}{ Item } & \multicolumn{2}{|c|}{ Treatment $^{1}$} & \multirow[b]{2}{*}{ SEM } & \multirow[b]{2}{*}{$P$-value } \\
\hline & $\mathrm{CON}$ & NA & & \\
\hline Calf BW, $\mathrm{kg}$ & 46.0 & 44.8 & 1.3 & 0.51 \\
\hline 0 -h IgG, g/L & 0.4 & 0.7 & 0.3 & 0.49 \\
\hline 24-h IgG, g/L & 15.9 & 16.1 & 0.6 & 0.75 \\
\hline $\mathrm{AEA},{ }^{2} \%$ & 26.4 & 25.9 & 1.0 & 0.71 \\
\hline
\end{tabular}

${ }^{1}$ Treatments: $\mathrm{CON}=$ control, basal TMR with $0 \mathrm{~g} / \mathrm{d}$ of nicotinic acid, $\mathrm{NA}=$ nicotinic acid; basal TMR with $48 \mathrm{~g} / \mathrm{d}$ of nicotinic acid.

${ }^{2} \mathrm{AEA}=[(24$-h plasma $\mathrm{IgG}(\mathrm{g} / \mathrm{L}) \times \mathrm{BW}(\mathrm{kg}) \times 0.0825) / \mathrm{IgG}$ intake $(\mathrm{g} / \mathrm{L})] \times 100$; Quigley and Drewry (1998), as modified by Cabral et al. (2015).

trum quality and decrease lipolysis, potentially leading to a decrease in metabolic disorders around calving. The effects of NA on the factors measured varied and agreed with our hypotheses in some cases.

Dry matter intake was not affected by NA. No effect on DMI was reported when feeding $12 \mathrm{~g} / \mathrm{d}$ NA to late-lactation dairy cows (Erickson et al., 1990, 1992; Campbell et al., 1994). In contrast, a 3.6\% increase in DMI was observed when feeding $12 \mathrm{~g} / \mathrm{d}$ NA (Di Costanzo et al., 1997).

Cow BW was not affected by NA supplementation, but we noted an effect of week. Average BW increased until 2 wk prepartum. Fetal growth is greatest during the last trimester (Bell, 1995), which most likely contributed to the increase in BW of the dam.

Nicotinic acid supplementation to the dam did not affect any of the calf parameters measured, including 0and 24-h serum IgG concentration, AEA, and calf BW. Previous research has found that IgG absorption is reduced in calves fed maternal colostrum from proteinor feed-restricted dams (Burton et al., 1984; Hough et al., 1990). However, in this study, to determine if NA supplementation to the dam had any effects on the calf in utero, calves were fed a commercial colostrum replacer, rather than maternal colostrum. Based on our results, NA supplementation to the dam did not affect IgG absorptive capacity or efficiency in the calf.

Urine $\mathrm{pH}$ was not affected by NA (Table 2). Normal $\mathrm{pH}$ of urine is around 8.2 when dairy cows are fed high-cation diets during lactation. Anionic salts are fed prepartum to prevent postpartum hypocalcemia by increasing mobilization of calcium from the bone (Riond, 2001). When administered properly, anionic diets should decrease urine $\mathrm{pH}$ to a range of 6.2 to 6.8 (Riond, 2001). Although urine $\mathrm{pH}$ was higher than the suggested range, we observed minimal incidence of metabolic disorders around calving. Ketosis treatment was administered to $4 \mathrm{CON}$ and $2 \mathrm{NA}$ cows, and milk fever treatment was administered to 1 NA cow. 
Serum glucose concentrations were not affected by NA, but we noted an effect of week (Table 2). Supplementation of NA did not affect glucose concentrations with NA supplementation in some cases (Erickson et al., 1990; Zimmerman et al., 1992; Yuan et al., 2012). However, increased serum glucose concentrations were observed with $14 \mathrm{~g} / \mathrm{d}$ NA (Karkoodi and Tamizrad, 2009) and $6 \mathrm{~g} / \mathrm{d}$ NA (Aschemann et al., 2012). Several studies corroborated this result (El-Barody et al., 2001; Neihoff et al., 2009b; Pescara et al., 2010). It is not known whether the effect of increased glucose concentration in the blood with NA supplementation is due to increased gluconeogenesis due to greater availability of coenzymes (NAD and NADP) and propionate, decreased extra-hepatic removal of glucose, or endocrine changes promoted by inhibiting lipolysis (Zimmerman et al., 1992; Di Costanzo et al., 1997; El-Barody et al., 2001).

Prepartum serum NEFA concentrations were not affected by NA supplementation (Table 2). During the prepartum period, DMI is typically reduced and this is accompanied by an increase in energy demand for colostrum and milk production. This results in a negative energy balance state, causing mobilization of adipose tissue and subsequent increase in serum NEFA. Supplemental NA has been shown to reduce lipolysis in some studies (Fronk and Schultz, 1979; Erickson et al., 1990; Pires et al., 2007), but not in others (Erickson et al., 1992; Drackley et al., 1998; Neihoff et al., 2009b). We detected a treatment by week interaction for postpartum serum NEFA concentrations (Table 2). At 1 wk postpartum, cows that were supplemented with NA prepartum had greater serum NEFA concentrations than CON cows (Figure 1), indicating that lipolysis was not reduced by NA. This result is the classic rebound effect that has previously been observed when NA was supplemented to dry cows (Waterman et al., 1972). The rebound effect was observed by Oh et al. (2011), where continuous infusion of NA in rats decreased NEFA, but once administration ceased, levels rebounded to more than twice the preinfusion levels. Those authors found that NA altered gene expression of phosphodiesterase, an enzyme responsible for degrading cAMP in adipocytes. Decreased expression of phosphodiesterase may have led to the sudden increase in lipolysis. In the current study, ceasing supplementation of NA at calving most likely exacerbated lipolysis, causing the increase, or rebound, of NEFA concentrations. This rebound is avoided when NA supplementation continues through positive energy balance (Morey et al., 2011).

Serum concentrations of BHB were not affected by NA supplementation; however, we noted an effect of week (Table 2). The threshold for subclinical ketosis is $1.4 \mathrm{mmol}$ of $\mathrm{BHB} / \mathrm{L}$ (Berge and Vertenten, 2014). Concentrations in the current study were below this threshold, indicating that cows were not in severe negative energy balance at 1 wk postpartum. Elevated serum BHB concentrations around parturition are common due to the increase in energy demand that cannot be met by diet alone. In an attempt to meet energy needs, cows will mobilize adipose tissue. When adipose tissue is mobilized too quickly, the liver is overloaded with NEFA. $\beta$-Oxidation in the liver is unable to keep up, causing an increase in ketone production (Harvey and Ferrier, 2011). For this reason, changes in levels of BHB typically follow closely behind changes in NEFA concentrations, which was observed in this study. $\beta$-Hydroxybutyrate is also an agonist for the GPR109A receptor, indicating that a negative feedback mechanism exists where high levels of BHB could reduce lipolysis (Taggart et al., 2005).

Yield of colostrum and fat percentage of colostrum were not affected by treatment (Table 3 ). These results are in agreement with previous work, where NA did not affect yield or fat percentage of milk (Campbell et al., 1994; Di Costanzo et al., 1997; Nielsen and Ingvartsen, 2003; Morey et al., 2011). However, other work did observe an increase in milk fat percentage with NA supplementation (Belibaskakis and Tsirgogianni, 1996). Although colostral lactose was not measured in this study, NA has not been shown to increase lactose content in milk. Solids percentage of colostrum was not affected by NA, which is in agreement with other work (Belibaskakis and Tsirgogianni, 1996; Morey et al., 2011). Yield of IgG was also not affected by NA treatment.

Colostrum protein percentage of cows supplemented with NA tended to be higher $(P=0.09$; Table 3$)$, which may be due to an increase in IgG concentration or to an increase in microbial protein production. Riddell et al. (1981) found a slight increase in milk protein percentage when cows were supplemented with NA in mid lactation, which the authors attributed to the greater microbial protein synthesis. Similar results were observed in early- and mid-lactation cows supplemented with NA (Erickson et al., 1992; Karkoodi and Tamizrad, 2009). Nicotinic acid supplementation may spare tryptophan, allowing more to be incorporated into milk protein (Flachowsky, 1993). However, several studies have reported no effect on milk protein with NA supplementation (Riddell et al., 1981; Dufva et al., 1983; Erickson et al., 1990).

Supplementation of NA increased colostral IgG concentration from 73.8 to $86.8 \mathrm{~g} / \mathrm{L}(P=0.01)$. Immunoglobulin $\mathrm{G}$ concentration may have been improved in 1 of 2 ways: (1) NA supplementation has been shown to 
cause vasodilation through activation of the GPR109A receptor, as previously described (Tunaru et al., 2003; Benyó et al., 2006). Therefore, by supplementing NA during colostrogenesis, blood flow to the mammary gland may have been increased, thus more IgG would be transferred into colostrum; or (2) NA supplementation has been shown to increase protozoa numbers in the rumen, specifically Entodinia species (Erickson et al., 1990; Doreau and Ottou, 1996; Aschemann et al., 2012). Entodinia species engulf starch particles, which results in a slow release of acetic acid that maintains ruminal pH (Williams and Coleman, 1992; Dehority, 2003). Stable rumen $\mathrm{pH}$ enhances proliferation of bacteria and therefore may increase microbial protein reaching the small intestine of the dam. Microbial protein synthesized in the rumen provides the majority of absorbable amino acids to the small intestine in the cow (Fatahnia et al., 2012). Therefore, an increase in amino acids could lead to an increase in IgG production.

Failure of passive transfer has been associated with increased risk of morbidity and mortality, increased veterinary costs, decreased growth rates, decreased milk production in the first and second lactations, and increased risk of being culled from the herd (Robison et al., 1988; DeNise et al., 1989). In the United States, $20 \%$ of calves do not achieve successful passive transfer (NAHMS, 2007) and $>60 \%$ of colostrum in the United States fails to meet industry standards (Morrill et al., 2012). Clearly, improvements can and need to be made in this area. Proper health, growth, and development in early life are critical to subsequent growth, development, and production of dairy heifers. A diseased calf cannot utilize ingested nutrients exclusively for growth and development; nutrients must be allocated to fight and repair any damages from pathogens. By improving colostrum quality and calf immunity, healthier heifers can be raised to become more successful and profitable dairy cows.

\section{CONCLUSIONS}

Supplemental NA in the prepartum period increased colostral IgG concentration by $18 \%$. Dry matter intake, urine $\mathrm{pH}$, colostrum yield, yield of IgG, and colostrum fat and solids percentage were not affected by NA. Serum glucose and BHB concentrations were not affected by NA. Prepartum serum NEFA concentrations were not affected by NA, indicating that lipolysis was not reduced. However, serum NEFA concentrations increased dramatically 1 wk postpartum in cows that received NA during the prepartum period, indicating that ceasing NA supplementation at calving caused a rebound effect. Calf BW, 0- and 24-h IgG concentration, and
AEA were not affected by NA supplementation in the dam. More research is necessary to elucidate possible mechanisms for the increase in colostral IgG concentration, such as microbial protein production and blood flow. These results suggest that dairy producers should feed NA to prepartum cows to improve colostrum quality.

\section{ACKNOWLEDGMENTS}

The authors thank Lonza (Basel, Switzerland) for financial support. Partial funding was provided by the New Hampshire Agricultural Experiment Station. This is Scientific Contribution \#2639. This work was supported by the USDA National Institute of Food and Agriculture (Washington, DC; NC-2042; accession number 1001283) project. The authors thank the Fairchild Teaching and Research Center (University of New Hampshire) staff for use of the animals and assistance throughout the study. The authors also thank M. Lunak (University of New Hampshire Cooperative Extension) for assistance with statistical analysis

\section{REFERENCES}

Abdouli, H., and D. M. Schaefer. 1986. Effects of two dietary niacin concentrations on ruminal fluid free niacin concentration, and of supplemental niacin and source of inoculum on in vitro microbial growth, fermentative activity, and nicotinamide adenine dinucleotide pool size. J. Anim. Sci. 62:254-262.

AOAC International. 1999. Official Methods of Analysis. 16th ed. AOAC International, Gaithersburg, MD.

AOAC International. 2006. Official Methods of Analysis. 18th ed. AOAC International, Gaithersburg, MD.

Arthington, J. D., M. B. Cattell, J. D. Quigley III, G. C. McCoy, and W. L. Hurley. 2000. Passive Ig transfer in newborn calves fed colostrum or spray-dried serum protein alone or as a supplement to colostrum of varying quality. J. Dairy Sci. 83:2834-2838.

Aschemann, M., P. Lebzien, L. Hüther, S. Döll, K. Südekum, and S. Dänicke. 2012. Effect of niacin supplementation on digestibility, nitrogen utilization, and milk and blood variables in lactating dairy cows fed a diet with a negative rumen nitrogen balance. Arch. Anim. Nutr. 66:200-214.

Barrington, G. M., T. B. McFadden, M. T. Huyler, and T. E. Besser. 2001. Regulation of colostrogenesis in cattle. Livest. Prod. Sci. 70:95-104

Belibaskakis, N. G., and D. Tsirgogianni. 1996. Effects of niacin on milk yield, milk composition, and blood components of dairy cows in hot weather. Anim. Feed Sci. Technol. 64:53-59.

Bell, A. W. 1995. Regulation of organic nutrient metabolism during transition from late pregnancy to early lactation. J. Anim. Sci. 73:2804-2819

Benyó, Z., A. Gille, C. L. Bennett, B. E. Clausen, and S. Offermanns. 2006. Nicotinic acid-induced flushing is mediated by activation of epidermal Langerhans cells. Mol. Pharmacol. 70:1844-1849.

Benyó, Z., A. Gille, J. Kero, M. Csiky, M. C. Suchankova, R. M. Nusing, A. Moers, K. Pfeffer, and S. Offermanns. 2005. GPR109A (PUMA-G/HM74A) mediates nicotinic acid-induced flushing. J. Clin. Invest. 115:3634-3640.

Berge, A. C., and G. Vertenten. 2014. A field study to determine prevalence, dairy herd management systems and fresh cow clinical conditions associated with ketosis in western European dairy herds. J. Dairy Sci. 97:2145-2154. 
Brandon, M. R., D. L. Watson, and A. K. Lascelles. 1971. The mechanism of transfer of Ig into mammary secretion of cows. Aust. J. Biol. Sci. 49:613-623.

Burton, J. H., A. A. Hosein, I. McMillan, D. G. Grieve, and B. N Wilkie. 1984. Immunoglobulin absorption in calves as influenced by dietary protein intakes of their dams. Can. J. Anim. Sci. 64(Suppl.):185-186.

Butler, J. E. 1969. Bovine immunoglobulins: A review. J. Dairy Sci. 52:1895-1909.

Cabral, R. G., C. E. Chapman, E. J. Kent, and P. S. Erickson. 2015. Estimating plasma volume in neonatal Holstein calves fed one or two feedings of a lacteal-based colostrum replacer using Evans blue dye and hematocrit values at various time points. Can. J. Anim. Sci. 95:293-298.

Campbell, J. M., M. R. Murphy, R. A. Christensen, and T. R. Overton. 1994. Kinetics of niacin supplements in lactating dairy cows. J. Dairy Sci. $77: 566-575$

Carlson, L. A. 2005. Nicotinic acid: The broad-spectrum lipid drug. J. Intern. Med. 258:94-114.

Dehority, B. A. 2003. Rumen Microbiology. Nottingham University Press, Nottingham, UK.

DeNise, S. K., J. D. Robison, G. H. Stott, and D. V. Armstrong. 1989. Effects of passive immunity on subsequent production in dairy heifers. J. Dairy Sci. 72:552-554.

Di Costanzo, A., J. N. Spain, and D. E. Spiers. 1997. Supplementation of nicotinic acid for lactating Holstein cows under heat stress conditions. J. Dairy Sci. 80:1200-1206.

Doreau, M., and J. F. Ottou. 1996. Influence of niacin supplementation on in vivo digestibility and ruminal digestion in dairy cows. J. Dairy Sci. 79:2247-2254.

Drackley, J. K., D. W. LaCount, J. P. Elliot, T. H. Klusmeyer, T. R. Overton, J. H. Clark, and S. A. Blum. 1998. Supplemental fat and nicotinic acid for Holstein cows during an entire lactation. J. Dairy Sci. 81:201-214.

Dufva, G. S., E. E. Bartley, A. D. Dayton, and D. O. Riddell. 1983. Effect of niacin supplementation on milk production and ketosis in dairy cattle. J. Dairy Sci. 66:2329-2336.

El-Barody, M. A. A., H. A. Daghash, and Z. B. H. Rabie. 2001. Some physiological responses of pregnant Egyptian buffalo to niacin supplementation. Livest. Prod. Sci. 69:291-296.

Erickson, P. S., M. R. Murphy, and J. H. Clark. 1992. Supplementation of dairy cow diets with calcium salts of long-chain fatty acids and nicotinic acid in early lactation. J. Dairy Sci. 75:1078-1089.

Erickson, P. S., A. M. Trusk, and M. R. Murphy. 1990. Effects of niacin source on epinephrine stimulation of plasma nonesterified fatty acid and glucose concentrations, on diet digestibility and on rumen protozoal numbers in lactating dairy cows. J. Nutr. 120:1648-1653.

Fatahnia, F., A. Shahsavar, H. R. Mirzaei Alamouti, H. Darmani Kohi, H. Amanlou, and M. Ahmadi. 2012. Influence of starch sources in prepartum diet on colostrum quality and blood immunoglobulin concentration in calves. Iranian J. Appl. Anim. Sci. 2:57-61.

Flachowsky, G. 1993. Niacin in dairy and beef cattle nutrition. Arch. Tierernahr. 43:195-213.

Fronk, T. J., and L. H. Schultz. 1979. Oral nicotinic acid as a treatment for ketosis. J. Dairy Sci. 62:1804-1807.

Frye, T. M., S. N. Williams, and T. W. Graham. 1991. Vitamin deficiencies in cattle. Vet. Clin. North Am. Food Anim. Pract. 7:217275.

Hannah, S. M., and M. D. Stern. 1985. Effect of supplemental niacin or niacinamide and soybean source on ruminal bacterial fermentation in continuous culture. J. Anim. Sci. 61:1253-1263.

Harvey, R., and D. Ferrier. 2011. Biochemistry. 5th ed. Lippincott, Williams and Wilkins. Philadelphia, PA.

Hough, R. L., F. D. McCarthy, H. D. Kent, D. E. Eversol, and M. L. Wahlberg. 1990. Influence of nutritional restriction during late gestation on production measures and passive immunity in beef cattle. J. Anim. Sci. 68:2622-2627.

Kang, I., S. Kim, and J. H. Youn. 2011. Effects of nicotinic acid on gene expression: Potential mechanisms and implications for wanted and unwanted effects of the lipid lowering drug. J. Clin. Endocrinol. Metab. 96:3048-3055.
Karkoodi, K., and K. Tamizrad. 2009. Effect of niacin supplementation on performance and blood parameters of Holstein cows. S. Afr. J. Anim. Sci. 19:249-259.

Larson, B. L., H. L. Heary Jr., and J. E. Devery. 1980. Immunoglobulin production and transport by the mammary gland. J. Dairy Sci. 63:665-671.

Lopez, J. W., S. D. Allen, J. Mitchell, and M. Quinn. 1988. Rotavirus and cryptosporidium shedding in dairy calf feces and its relationship to colostrum immune transfer. J. Dairy Sci. 71:1288-1294.

Lorenzen, A., C. Stannek, H. Lang, V. Andrianov, I. Kalvinsh, and U. Schwabe. 2001. Characterization of a G-protein coupled receptor for nicotinic acid. Mol. Pharmacol. 59:349-357.

Morey, S. D., L. K. Mamedova, D. E. Anderson, C. K. Armendariz, E. C. Titgemeyer, and B. J. Bradford. 2011. Effects of encapsulated niacin on metabolism and production of periparturient dairy cows. J. Dairy Sci. 94:5090-5104.

Morrill, K. M., E. Conrad, A. Lago, J. Campbell, J. Quigley, and H. Tyler. 2012. Nationwide evaluation of quality and composition of colostrum on dairy farms in the United States. J. Dairy Sci. 95:3997-4005.

Murphy, M. R. 1982. Analyzing and presenting pH data. J. Dairy Sci. 65:161-163.

NAHMS (National Animal Health Monitoring System). 2007. Colostrum feeding and management on U.S. Dairy Operations, 19912007. Accessed Apr. 1, 2015. http://nahms.aphis.usda.gov/dairy/ dairy07/Dairy07_colostrum.pdf.

Neihoff, I., L. Huther, and P. Lebzien. 2009a. Niacin for dairy cattle: A review. Br. J. Nutr. 101:5-19.

Neihoff, I., L. Huther, P. Lebzien, W. Bigalke, S. Danicke, and G. Flachowsky. 2009b. Investigations on the effect of a niacin supplementation to three diets differing in forage-to-concentrate ratio on several blood and milk variables of dairy cows. Arch. Anim. Nutr. 63:203-218.

Nielsen, N., and K. L. Ingvartsen. 2003. A review of the effects of feeding niacin to early lactation dairy cows. Acta Vet. Scand. 44(Suppl. 1):129.

NRC. 2001. Nutrient Requirements of Dairy Cattle. 7th rev. ed. Natl. Acad. Press, Washington, DC.

Oh, Y. T., K. Oh, Y. M. Choi, A. Jokiaho, C. Donovan, S. Choi, I. Kang, and J. H. Youn. 2011. Continuous 24-h nicotinic acid infusion in rats causes FFA rebound and insulin resistance by altering gene expression and basal lipolysis in adipose tissue. Am. J. Physiol. Endocrinol. Metab. 300:E1012-E1021.

Pescara, J. B., J. A. A. Pires, and R. R. Grummer. 2010. Antilipolytic effects of administering free or ruminally protected nicotinic acid to feed-restricted Holstein cows. J. Dairy Sci. 93:5385-5396.

Pires, J. A. A., J. B. Pescara, and R. R. Grummer. 2007. Reduction of plasma NEFA concentration by nicotinic acid enhances the response to insulin in feed-restricted Holstein cows. J. Dairy Sci. 90:4635-4642.

Quigley, J. D., and J. J. Drewry. 1998. Nutrient and immunity transfer from cow to calf pre- and postcalving. J. Dairy Sci. 81:2779-2790.

Quigley, J. D. III, D. L. Fike, M. N. Egerton, J. J. Drewry, and J. D. Arthington. 1998. Effects of a colostrum replacement product derived from serum on immunoglobulin $\mathrm{G}$ absorption by calves. J. Dairy Sci. 81:1936-1939.

Riddell, D. O., E. E. Bartley, and A. D. Dayton. 1981. Effect of nicotinic acid on microbial protein synthesis in vitro and on dairy cattle growth and milk production. J. Dairy Sci. 64:782-791.

Riond, J. L. 2001. Animal nutrition and acid-base balance. Eur. J. Nutr. 40:245-254.

Robison, J. D., G. H. Stott, and S. K. DeNise. 1988. Effects of passive immunity on growth and survival of the dairy heifer. J. Dairy Sci. 71:1283-1287.

Sasaki, M., C. L. Davis, and B. L. Larson. 1976. Production and turnover of IgG1 and IgG2 immunoglobulins in the bovine around parturition. J. Dairy Sci. 59:2046-2055.

Taggart, A. K. P., J. Kero, X. Gan, T. Q. Cai, K. Cheng, M. Ippolito, N. Ren, R. Kaplan, K. Wu, T. K. Wu, L. Jin, C. Liaw, R. Chen, J. Richman, D. Connolly, S. Offermanns, S. D. Wright, and M. G. Waters. 2005. (D)- $\beta$-hydroxybutyrate inhibits adipocyte 
lipolysis via the nicotinic acid receptor PUMA-G. J. Biol. Chem. 280:26649-26652.

Titgemeyer, E. C., L. K. Mamedova, K. S. Spivey, J. K. Farney, and B. J. Bradford. 2011. An unusual distribution of the niacin receptor in cattle. J. Dairy Sci. 94:4962-4967.

Trinder, P. 1969a. Determination of blood glucose using 4-amino phenazone as oxygen acceptor. J. Clin. Pathol. 22:246.

Trinder, P. 1969b. Determination of glucose in blood using glucose oxidase with an alternative oxygen acceptor. Ann. Clin. Biochem. $6: 24-27$.

Tunaru, S., J. Kero, A. Schaub, C. Wufka, A. Blaukat, K. Pfeffer, and S. Offermanns. 2003. PUMA-G and HM74 are receptors for nicotinic acid and mediate its anti-lipolytic effect. Nat. Med. 9:352-355.
Waterman, R., J. W. Schwalm, and L. H. Schultz. 1972. Nicotinic acid treatment of bovine ketosis I. Effects on circulatory metabolites and interrelationships. J. Dairy Sci. 55:1447-1453.

Williams, A. G., and G. S. Coleman. 1992. The Rumen Protozoa. Springer-Verlag Inc., New York, NY.

Yuan, K., R. D. Shaver, S. J. Bertics, M. Espineira, and R. R. Grummer. 2012. Effect of rumen-protected niacin on lipid metabolism, oxidative stress, and performance of transition dairy cows. J. Dairy Sci. 95:2673-2679.

Zimmerman, C. A., A. H. Rakes, T. E. Daniel, and B. A. Hopkins. 1992. Influence of dietary protein and supplemental niacin on lactational performance of cows fed normal and low fiber diets. J. Dairy Sci. 75:1965-1978. 